\title{
Research Report on Internal Audit of Unlisted Private Enterprises in Yancheng, China
}

\author{
Wei Wei ${ }^{1}$ \\ ${ }^{1}$ Graduate School of Management, Tokyo Metropolitan University, Tokyo, Japan \\ Correspondence: Wei Wei, Graduate School of Management, Tokyo Metropolitan University, 1-1 \\ Minami-Osawa, Hachioji-shi, Tokyo, Japan. E-mail: andywaiwai@126.com \\ Received: February 1, 2020 \\ Accepted: April 27, 2020 \\ Online Published: May 15, 2020 \\ doi:10.5539/ijbm.v15n6p105 \\ URL: https://doi.org/10.5539/ijbm.v15n6p105
}

\begin{abstract}
The rapid development of the private economy in China has put forward higher requirements for a sound supervision system in the enterprises. However, compared to the sate-owned enterprises or listed private enterprises, because of the lack of the official constraints or guidance on the internal audit, the development of internal audit in unlisted private enterprises are still facing many problems. This paper conducted questionnaire-based investigation on the unlisted private enterprises in Yancheng of Northern Jiangsu Province in China, in order to obtain detailed information related to the internal audit of unlisted private enterprises. Through the analysis on the information gathered from questionnaires and the typical study on the case of a large-scale unlisted private enterprise, SD group in Yancheng, suggestions were put forward to improve the current situation of internal audit in unlisted private enterprises in Yancheng, which also can help to promote the development of private economy in Yancheng, and thus contribute to the economic development in Jiangsu, or even in the whole China.
\end{abstract}

Keywords: unlisted private enterprise, internal audit, corporate governance, internal control

\section{Introduction}

In recent years, China Securities Regulatory Commission has issued a series of regulations to lay further supervision on the listed enterprises. Thus, under the supervision of the government institutes, the internal audit of listed private enterprises is better in terms of internal organizations, personnel, audit methods and techniques, and other aspects. However, the unlisted private enterprises are the main part of China's private economy. Nowadays, internal audit has become an essential part of corporate governance, risk management and internal control, which plays an important role in the sustainable development of unlisted private enterprises. But due to the insufficient awareness of the functions of internal audit, a large percentage of the unlisted private enterprises in China haven't established independent internal audit departments. What's more, the lack of regulation restraint and standardized guidance on internal control, internal audit and risk management leads to various problems in the internal audit of unlisted private enterprises, including the disordered organizational, insufficient staffing, and the limited internal audit scope. Thus, in this research paper, we carried out investigations on the internal audit of unlisted private enterprises and propose improving suggestions based on the existing limitations.

The definition of the unlisted private enterprises needs to be divided into two parts, namely, "unlisted enterprises" and "private enterprises". The "unlisted enterprises" means that the shares of which are not issued and traded publicly on the stock exchange. And the so-called "private enterprise" is a concept corresponding to "state-owned enterprises", of which the organization forms are non-state-owned and unofficial. Usually, the enterprises without state capital are defined as private enterprises. Therefore, the unlisted private enterprises in this report refers to those enterprises which have neither issued shares publicly in the securities market, nor received investment from the state capital.

Jiangsu Province is located on the East Coast of mainland China, which is one of the most active provinces in China, ranking the first in China in terms of comprehensive economic competitiveness. The northern district of Jiangsu Province has always been regarded as a relatively backward area in economic development. However, in recent years, with the implementation of the provincial development strategies, northern Jiangsu has become one of the most important economic developing regions in East China, and the fastest developing area of China in recent 5 years. Yancheng City is the author's hometown. It is the largest provincial city among the five cities in 
northern Jiangsu district, with a GDP of 427.5 billion CNY in 2015, and has surpassed most of other the cities in other districts of Jiangsu. In recent years, the total amount of private economy in Yancheng has been expanding. In 2015, the city's private economy realized a regional GDP of 286.4 billion CNY, which is nearly twice as much as in 2005 , and accounting for $66.99 \%$ of the city's regional GDP. Therefore, investigation on the internal audit of unlisted private enterprises within Yancheng can help to find out the existing weakness of the internal audit and put forward countermeasures to make internal audit play a better role of internal supervision and risk control, thus further promote the healthy and rapid development of the private economy in Jiangsu, and even in the whole China.

\section{Literature Review}

\subsection{Research on the Functions of Internal Audit}

Before the 1990s, scholars mainly focused on the traditional functions of internal audit. Flint (1988) believes that, supervision is the most important function of internal audit, which means, internal audit can effectively supervise the management's entrusted economic responsibility within the organization. After the 1990s, scholars focused more on the consulting function of internal audit. Chambers (1992) considers that internal audit serves for the company's management activities. It can help the management analyze the operating outcomes, and illustrate the reasons for differences from the plan, so as to effectively carry out its consulting function. Carmichael and Willingham (1997) argue that internal audit should perform its assurance function to provide a higher level of assessment. From then on, internal audit has evolved from traditional functions to assurance and consultancy. Whittington and Pany (2001) make it clear that, when evaluating and measuring the internal control, internal audit should also pay attention to the effects of other sections. Yuan (2002) point out that internal audit should be flexible to adapt to the changes in the external environment. It should be an effective role in optimizing enterprise management, adding value to enterprises, providing management consulting services, and supervising and evaluating internal control. Jia (2009) believes that, internal audit should not be constrained to the current scope, but be more proactive in participating in corporate strategy, and effectively offer evaluation and consulting services during the implementation of corporate strategic decisions. Arens (2010) concludes that when an entity orientates the function of internal audit, it should not separate from the actual situation of the enterprise itself. Different enterprises have different functional requirements for internal audit. Besides, internal audit should not be oriented only on the traditional supervision and assurance functions, instead, should focus on risk control to help in preventing risks and gaining profits.

\subsection{Research on Internal Audit in Private Enterprises}

Through the literature review on researches of internal audit conducted by the scholars out of China, we found that, there is no specific classification between private enterprises and state-owned enterprises. Also, researches on internal audit in private enterprises in China only started from the beginning of this century. Tan et al. (2003) discusses the characteristics of the internal audit of private enterprises in China based on the theory of environmental impact, and proposes the countermeasures and suggestions for continuous development of internal audit in private enterprises. Tian and Qiu (2005) analyzes the current problems of internal audit in the private enterprises and put forward solutions from the perspectives of organizational model, performance assessment, regulatory system, internal auditors' qualifications, and so on. Zhang and Yang (2012) investigate on 36 private enterprises by surveys to get to know the present situation of internal audit, including the establishment of internal audit, the personnel, internal audit scope and internal audit methods and techniques, thus to summarize the deficiencies on internal audit and thus propose suggestions for improvement.

\section{Research Method}

Before the on-site research, we communicated with the Internal Auditors Association of Yancheng. We were told that, there is no statistical data on the basic situation of the internal audit of private enterprises in this city. Thus, in this paper, we conducted investigation on the unlisted private enterprises in Yancheng to obtain related information by questionnaires. The situation of internal audit mainly includes the establishment, personnel, business scope and methods and techniques of internal audit. This research report also dissects the typical case of the internal audit of SD group in Yancheng through the introduction of current situation of it and then makes a proposal of improving schemes based on the investigation of the internal audit of unlisted private enterprises in Yancheng.

\subsection{Design of Questionnaire}

In order to collect more detailed information on internal audit, the main contents of the questionnaires include the basic information of enterprises, the establishment and independence of the internal audit department, the 
professional qualifications of internal auditors, the performance of internal audit, the future orientation, and so on. The questionnaire is in a form of multiple choice, which are easy to be answered and tallied. On the basis of presenting the current situation of internal audit, we also ask those who are surveyed to express their own opinions related to the internal audit of their enterprises.

\subsection{Investigation Procedure and Data Collection}

This investigation was completed during the author's working period in the Local Taxation Bureau in Yancheng, which was also supported by the staff of the taxation bureau. The questionnaires were mainly distributed and collected during the tax inspection or tax training held by the taxation bureau. Also, some were sent to the contactors of the enterprises and replied by email.

In order to make this survey cover most of the private enterprises in this city, we classified all the enterprises according to the districts, and ensured that enterprises in all the three municipal districts and five counties in this city would be covered. Then, according to the close relations between the scale of the enterprise and the establishment of internal audit department, we selected the target enterprises of survey based on the registered information in the tax system, including the number of employees, the registered capital and the annual sales revenue of 2015. As shown in Table 1, that information was converted into measuring scores. The enterprises with more than 1000 employees would get 3 points. If the number of employees is from 500 to 999 , they could get 2 points. Those with employees from 100 to 500 could get 1 point. But if under 100, they would get no point. For registered capital in 2015, enterprises with registered capital over 100 million CNY would get 4 points, if the capital is between 50 million CNY and 100 million CNY, they would get 3 points, if between 20 million CNY and 50 million CNY, they would get two points, and if between 3 million CNY to 20 million CNY, they would only get 1 point. The others with a registered capital below 3 million CNY would not get any point. And if the sales revenue of 2015 exceeds 400 million CNY, 4 points would be counted. If the sales revenue is over 50 million CNY but less than 400 million CNY, 3 points would be counted. If the sales revenue is between 20 million CNY and 50 million CNY, 2 points would be counted. If the sales revenue is between 5 million CNY and 20 million CNY, 1 point would be counted. If the sales revenue is below 5 million CNY, no point would be counted. Finally, in each district, the enterprises which would be investigated are decided according to the final scores. Questionnaires will be distributed to all unlisted private enterprises of 9 points or more. Enterprises with a total score from 6 to 8 points are randomly selected according to the proportion of $30 \%$, and enterprises with a total score from 3 to 5 points are selected according to the proportion of $10 \%$, as shown in Table 2 . As a result, a total of 685 questionnaires were issued, and 127 questionnaires were received.

Table 1. Scores conversion standard

\begin{tabular}{llll}
\hline Scores & Number of employees & $\begin{array}{l}\text { Registered capital of 2015 } \\
\text { (million CNY) }\end{array}$ & $\begin{array}{l}\text { Sales revenue of 2015 } \\
\text { (million CNY) }\end{array}$ \\
\hline 4 & Over 1000 & Over 100 & Over 400 \\
3 & From 500 to 1000 & From 50 to 100 & From 50 to 400 \\
2 & From 100 to 500 & From 20 to 50 & From 20 to 50 \\
1 & Less than 100 & From 3 to 20 & From 5 to 20 \\
0 & & Less than 3 & Less than 5 \\
\hline
\end{tabular}

Table 2. Sampling of questionnaires

\begin{tabular}{llll}
\hline Scores & Total number & Sampling percentage & Sampling number \\
\hline Over 9 & 91 & $100 \%$ & 91 \\
From 6 to 8 & 1204 & $30 \%$ & 361 \\
From 3 to 5 & 2329 & $10 \%$ & 233 \\
\hline
\end{tabular}

\section{Results}

\subsection{Establishment of Internal Audit Department}

According to the statistics collected from questionnaires, 73 unlisted private enterprises have already set up internal audit department. Among the enterprises with a score of 9 points or more, 47 of them have set up internal audit department, and among the enterprises with scores from 6 to 8 points, 19 have set up internal audit 
department. And among those with a score from 3 to 5 points, only seven enterprises have set up internal audit department, as referred in the Table 3. Also, those statistics show that, the establishment of internal audit department has a significant positive correlation with the size of the enterprises.

Table 3. Establishment of internal audit departments in the investigated enterprises

\begin{tabular}{llll}
\hline Scores & Total number of enterprises & Sampling number & $\begin{array}{l}\text { Number of enterprises with } \\
\text { internal audit }\end{array}$ \\
\hline Over 9 & 91 & 91 & 47 \\
From 6 to 8 & 1204 & 361 & 19 \\
From 3 to 5 & 2329 & 233 & 7 \\
\hline
\end{tabular}

Among those 73 enterprises with internal audit department, there are only 39 enterprises that have independent internal audit department, while 28 enterprises have their internal audit offices under the finance department. And the other 6 enterprises set the internal audit offices under the line of legal affairs department or other supervision department. Only one of those enterprises has established its internal audit department over 15 years, 2 enterprises have the internal audit department around10 to 15 years, and 32 enterprises have the department from 5 to 10 years. More than half of those enterprises just establish the internal audit departments in recent past 5 years. 23 enterprises are planning to go public recently, and 17 of them have equipped with independent internal audit department. 45 enterprises' internal audit departments directly report to the board of directors, and 16 of them also report to the board of supervisors or audit committee at the same time. The others report to the general manager, vice general manager or the persons in charge of the financial department or other supervision department.

Overall, although only a small number of unlisted private enterprises in Yancheng have equipped with internal audit department, compared with the situation of 10 years ago, the internal audit in private enterprises within the city has developed greatly. However, the independence and authority of internal audit departments need to be further improved. Therefore, the internal audit in unlisted private enterprises is still under the initial stage. Besides, among the 23 enterprises which are preparing to go public, 17 enterprises have set up independent internal audit institutions, formulated the internal audit rules, and implemented a mode of direct leadership by the board of directors, the board of supervisors or the audit committee. Thus, under guidance of going public, the private enterprises planning to go public have a better internal audit management system than the enterprises without such plans.

\subsection{Professional Qualifications of Internal Auditors}

The total number of internal auditors in all the 73 enterprises with internal audit department is 238 , but only 153 of them are full-time auditors, while the others are part-time auditors, holding a concurrent position in other department in the enterprises, such as financial department or administrative department. Besides, among of all the 238 internal auditors, 117 auditors have a degree of bachelor or above, 56 auditors have intermediate professional title or above, 8 auditors hold the certification of Certified Internal Auditor and 11 auditors hold the certification of Certified Public Accountant of China.

Usually, the number of internal auditors is positive related to the enterprise size. But according to investigation, some enterprises of large scale have few internal auditors, or only have part-time internal auditors, while some enterprises are of relatively small size, but equipped with full-time and professional internal auditors. The statistics also show that, internal audit staffing situation in this city is related to whether the enterprise is preparing for going public. Among the 23 enterprises with the plan of going public, all of them have staffed with full-time internal auditors. They have 35 full-time internal auditors and 21 part-time auditors. Also, 5 auditors have the certification of CIA and 3 auditors have the certification of CPA. Therefore, under the vision of planning to go public, enterprises would improve their staffing of professional internal auditors.

Within all the private enterprises under investigation, the management or the owners of the enterprises showed great support to the implementation of internal audit. In terms of the further education or professional training, all enterprises equipped with internal audit departments showed their willing to offer every auditor more than $1000 \mathrm{CNY}$ per year to participate in professional trainings, and 34 enterprises are willing to provide over more than 5000 CNY per person every year. However, in most enterprises, the internal auditors only participated in the 
financial and tax knowledge training courses that conducted by the governmental financial sections or external training institutions. Only 5 enterprises' internal auditors have participated in the special internal audit training given by the Internal Auditors Association of this city.

\subsection{Business Scope of Internal Audit}

The business scope of internal audit differs according to the enterprise's industry, the operation mode and the management style. From the overall information collected from the survey, the unlisted private enterprises in this city mainly conduct internal audit on economic responsibility, operation performance, accounting frauds and financial reports. In addition to the basic business scope of internal audit mentioned above, some enterprises also carry out special audit according to the characteristics of their business. For example, the JP Agrochemical Limited Company is under rapid expansion recent years, and several new plants have been built, or still under construction. Thus, it conducted the special audit on the construction projects. KY Group is mainly engaged in garment production and sales. Its internal audit department also conducts price audit on the procurement of materials every year. However, despite there is a wide business scope of internal audit inner those enterprises, only 11 enterprises have carried out the internal control audit or risk management audit, and none of them has carried out information system audit.

\subsection{Methods and Techniques of Internal Audit}

According to the investigation, more than $50 \%$ of the enterprises only conduct the post audit. Although the other enterprises also implement interim audit, they still mainly focus on the post audit. Only three enterprises conduct prior audit, interim audit, and post audit simultaneously. The internal audit of unlisted private enterprises in Yancheng is still in the stage of combining finance-based audit with control-oriented audit. Only 7 enterprises have changed from control-oriented audit mode to risk-oriented audit mode.

Additionally, the unlisted private enterprises tend to choose the audit methods which are suitable for their own enterprises according to the characteristics of the industries they involved or requirements for sustainable developments. For example, a private enterprise, SY Limited Company, which mainly manufactures and sells the parts for passenger coaches, tends to adopt the audit techniques such as sampling, statistics, inspection, inventory count, and inquiry, to adapt to the enterprise's traditional financial management and operation mode. JP Agrochemical Limited Company has production lines in several counties and districts. In order to cooperate with the efficient application of ERP systems, the internal audit usually conducted in a combination of on-site audit and computer aided audit.

\section{Case Study on the Internal Audit of SD Group}

With the fierce competition in the market, enterprises have to constantly improve their operations and management, thus they can survive in the market for a longer time. Internal audit is regarded as one of the important means for enterprises to strengthen the corporate management and improve the operating efficiency. The previous parts of this paper have described the general situation of the internal audit in the unlisted private enterprises within Yancheng. In this part, a typical case study of SD Group are conducted to analyze on how a unlisted private enterprises could continuously improve its internal audit and establish a scientific and efficient internal audit system to further improve its operating efficiency, and achieve the value-added goal.

\subsection{Introduction on SD Group}

The SD Group is a typical private enterprise which emerged from the reform and opening up period. In 1977, the current chairman of the SD Group set up a leather shoe factory in a dilapidated cowshed. After ten years of hard-working period, it ranked in the top three of leather shoes industry in Jiangsu Province. In 1993, SD became the largest shoe manufacturer in the world, and received the highest domestic honor in the industry. In 1998, the group had over 10,000 employees, achieved an annual sales revenue of 1.32 billion CNY. In the end of the last century, the development of the SD Group reached its peak. However, in 2007, due to the break of capital chain, the SD Group signed a restructuring agreement with Hong Kong BL Group. Under this agreement, the BL Group acquired all the shoes manufacturing subsidiaries of the SD Group at a price of approximately 2.1 billion CNY. After that, SD Group, the former King of the shoes manufacturing industry in China, sold all of the shoes related assets, and withdrew from the shoe manufacturing industry.

After the withdrawal from the shoes industry, there are only four sole subsidiaries under the SD Group, including the SD Thermal Power Ltd., SD Bioengineering Ltd., LR Fashion Ltd., and HF Microfinance company. At present, the thermoelectric industry has become the main operating direction of the SD Group. The sales revenue of the whole Group in 2015 reached 1.24 billion CNY, still ranking in the forefront among the unlisted private enterprises in Yancheng. 
The SD Group is a typical family enterprise. The chairman of the board is the owner, and the present general manager is the eldest son of the chairman. Many members of top management are in close relationship with the chairman, which also leads to a high concentration of business decision-making power of management. In the early stage of the development, the highly concentrated decision-making power could make the enterprise timely and flexibly response to the market changes. However, with the expansion of the market share and the scale of the company, the initial management team of the SD Group was unable to meet the needs of operation and management. So the management team needed more talents. However, in this family enterprise, due to the complex nepotism, more and more relatives of the family entered into the core management, which is one of the main reasons for the operation crisis in 2007. After the M\&A in 2007, SD Group still remains its form of family business. Most of the previous management team members have become the management staff of its subsidiaries.

\subsection{Development History of Internal Audit in SD Group}

\subsubsection{Initial Stage of Internal Audit}

In the initial stage of the enterprise, the business scale of the group was relatively small. The organizational structure was very simple, and the information exchange among departments was relatively smooth. At that time, internal audit was not conducted. But after 1993, with the extension of its manufacturing scale, branches and subsidiaries were set up. Financial department of the headquarters began to conduct inspection on the financial information of those subsidiaries, which is actually similar to the function of internal audit. So it could be said that, the internal audit of the group began to sprout during this period.

\subsubsection{Internal Audit Office under the Financial Department}

With the further extension of the business scale, more and more cross-regional subsidiaries and branches emerged gradually, which made the enterprise owner realize the importance of enhance supervision on the internal management of the whole enterprise. Thus, SD Group set up an internal audit office under the financial department in the headquarters from 1997. A financial staff concurrently held the post of internal audit and reported to the chief financial officer. The internal audit office conducted financial audit on branches and subsidiaries once a year as required. When there were a lack of personnel to conduct internal audit, the financial staff from other subsidiaries were asked to attend the audit under the instruction of the internal auditor. In this period, the internal audit in SD Group was of a restricted working scope and weak independence.

\subsubsection{Independent Internal Audit Department}

With the diversification in operation of SD Group, the internal audit office was required require to conduct audit more than the regular financial audit. In 2004, SD Group established an independent audit department equipped with 2 full-time auditors, including a chief internal auditor. The chief internal auditor directly reports to the general manager. From then on, the internal audit office was officially separated from the financial department. Besides, the business scope of internal audit was extended from financial audit to performance audit and off-office audit on the managers.

However, although the internal audit department was independent from the financial department, because of complex nepotism inside of the SD Group, when conducting internal audit, if there was kinship between the auditee and the chairmen or general manager, auditors would have concerns which might affect the independence of the internal audit work. As a result, the audit result could not reflect the actual problems which should be disclosed and improved. Before being acquired in 2007, because of the loose management mode, some of the senior management were always considering how to take forcible possession of enterprise's asset, rather than thinking of how to improve the performance and add value to the enterprise. For example, some sales managers of branches reported the receivables had become bad debt, while they had already received the payment from the customers in personal ways. For this kind of fraudulent behavior, internal auditors could not report the actual audit result to the group due to the specialty of the auditees. Thus, the internal audit could not effectively act on the fraud detection and risk prevention.

\subsubsection{Exploration of Management Audit}

Due to the need of business transformation, the chairman of the board began to realize the importance of management audit. In order to gradually improve the working process of internal audit and establish the internal audit management system, SD group engaged 2 more professional auditors with rich experience on internal audit in 2014. However, at present, the management audit of SD group is still under the exploratory stage. With the help of external consulting firms, it begins to establish a mature internal control system and internal audit management system. 
The development of the internal audit in SD group is basically synchronous with that of most private enterprises in Yancheng. The SD Group is a typical case among the unlisted private enterprises in Yancheng, thus the existing deficiencies of internal audit in SD group are also the common problems wide spreading in the unlisted private enterprises in Yancheng, or the whole China.

\section{Suggestions on Improving the Internal Audit in Unlisted Private Enterprises}

According to the analysis above, we concluded some common problems in the internal audit of unlisted private enterprises in Yancheng, such as insufficient knowledge of internal audit, unreasonable establishment of internal audit department, personnel shortage, limited audit scope, and backward audit methods and techniques. At present, the operation of internal audit still cannot meet the requirements for the effective management inside the unlisted private enterprises. However, to set up a sound internal audit system inside the unlisted enterprises is a long-term process. It is necessary to take the characteristics and external environment of enterprises as the starting point, and gradually improve the internal audit of enterprises in a planned and purposeful way.

\subsection{Issuing Guidelines on Internal Audit in Unlisted Private Enterprises}

To enhance the awareness of the importance of internal audit is an initial precondition to improve the implementation of internal audit in unlisted private enterprises. At present, there is a prominent problem in private enterprises, which is many enterprises think it is unnecessary to establish internal audit department in their organizations. With the continuous introduction of relevant regulations and guidance documents on the internal audit of listed companies, the internal audit inside listed companies has gradually become gradually standardized. Therefore, China's government supervision department is in urgent need for formulating regulations and guidance on the internal audit of unlisted private enterprises. Those guidelines should help to improve the present problems such as the establishment, the personnel and audit procedures, inside the enterprises, and be conducive to improving the internal audit work of unlisted private enterprises in China and promoting the healthy development of private economy in China.

\subsection{Establishing Independent Internal Audit Department}

Enterprise should establish the independent internal audit department based on its business scale, organizational structure, management system and other aspects. And affiliation of the internal audit department is the essence for the independence of the internal audit department. When establish internal audit departments, the personnel in charge of the internal audit department should directly be responsible to the top management, and can directly report to the board of directors. The chief internal auditor should be nominated by the board of directors. The internal audit department should formulate the Internal Audit Charter and periodically assess the charter to ensure it is adapted to the development of enterprises and the authorities defined in the charter can assist the internal auditors to accomplish their auditing tasks. For some small and micro unlisted private enterprises of simple operating mode, there is less control risk in the corporate management. Thus, it is of little necessary for them to set up an independent internal audit department to conduct regular internal audit. They can outsource the internal audit, and be audited by the outside institutes when there is a requirement for internal audit.

\subsection{Improving the Professional Qualifications of Internal Auditors}

A qualified internal audit team is the precondition of smooth implementation of internal audit inside the enterprises. Because of the diversity and complex of the operating environment, internal auditors are required to command not only the professional knowledge on finance and audit, but also the theory and practical capability on economy, management, marketing and other fields. From the questionnaires collected in Yancheng City, we consider that the internal auditors of unlisted private enterprises are of lower professional qualifications. Thus, we suggest the enterprises should recruit more comprehensive audit talents, and enhance the continuous training of internal auditors through participation in professional seminars, or they can outsource the professional training to external training centers, thus to improve the professional qualifications of internal auditors in unlisted private enterprises.

\subsection{Extending the Business Scope of Internal Audit}

According to the survey, most of the internal audit in unlisted private enterprises in Yancheng is still restricted on the financial audit of fraud prevention. The business scope of internal audit in unlisted private enterprises is comparatively limited. The ultimate purpose of conducting internal audit is to optimize the operation and management inner enterprises, and promote the sustainable development of the enterprises. Therefore, the internal audit in unlisted private enterprises should be transformed from financial audit to management audit. The audit department should not only be able to discover the problems in the process of business management, but also be able to actively analyze the causes of the problems and put forward effective suggestions. Besides, 
internal audit should also help to improve the system construction inner enterprises and effectively promote the internal control, risk management, business innovation and other activities of enterprises from the perspective of management.

\subsection{Improving the Internal Audit Methods and Techniques}

Among the unlisted private enterprises in Yancheng, most of them only conducted post audit, while only a few implemented prior audit, interim audit and post audit simultaneously. In order to fundamentally prevent risks, improve the operation and increase the value, the enterprises should abandon the original internal audit mode, and become focusing on the risk management. The internal audit should concentrate on the business objectives of the enterprises, and gradually pay attention to prior audit and interim audit. Guided by risk management, the internal audit could conduct comprehensive analysis in advance, actively prompt potential risks, and thoroughly supervise the activities of the enterprise.

With the exploitation and application of accounting information system, the internal audit of unlisted private enterprises is also confronted with challenges from information technology. The original audit method is no longer adapted to the demand of information management. A complete audit information platform can be built in the enterprises to provide timely supervision and assessment on finance, procurement, sales or other segments. Through the application of information technology in audit, the online audit or long-distance audit can be conducted without restriction on location for internal auditors. At the same time, information technology audit can automatically retrieve and calculate data, thus it can effectively reduce the possible errors in manual audits and improve the quality of internal audit.

\section{Conclusions}

The internal audit of private enterprises in Yancheng has developed vigorously in the past ten years. But compared with the speed of the expansion of business scale, the development of internal audit is relatively slow, which cannot fully meet the requirements and expectations of the enterprises. Through the analysis on the results of surveys on the unlisted private enterprises in the city, the problems and deficiencies of internal audit in most of the unlisted private enterprises mainly include insufficient knowledge of internal audit, unreasonable establishment of internal audit department, personnel shortage, limited audit scope and backward audit methods and techniques.

Based on the above common problems, the internal audit of unlisted private enterprises could be improved through governmentally issuing guidelines on internal audit of unlisted private enterprises, establishing independent internal audit department inner enterprises, improving the professional qualifications of internal auditors, extending the business scope of internal audit, transferring the internal audit methods into risk oriented audit, and adopting the information system based audit techniques.

The implementation of internal audit should be combined with the enterprise's situation and characteristics. Due to the limitation of time, this paper only analyzed the common situation of the internal audit in unlisted private enterprises in Yancheng, which is under the period of rapid economic growth. The unlisted private enterprises of other economically under-developed area in China, may have other kinds of deficiencies on the internal audit. Besides, the case study is made on a typical manufacturing-type enterprise, while the other types of unlisted private enterprises may have different situation, such as real estate enterprises and microfinance institutions. Therefore, in the future, supplemental investigations need to be conducted, and this research report could be further enriched.

\section{References}

Albrecht, W. S., Howe, K. R., Schueler, D. R., \& Stocks, K. D. (1988). Evaluating the effectiveness of internal audit departments. Institute of Internal Auditors Research Foundation.

Alvin, A. A., Randal, J. E., \& Mark, S. B. (2010). Auditing and assurance services: an integrated approach. Pearson Publishing.

Bradford, K. (1964). Operational Auditing Handbook. Southwestern College Publishing.

Brink, V. (1941). Internal Auditing-Function and Methods of Procedure. The Ronald Press Company.

Cai, C. (1996). Discussions on the functions, objectives and realization conditions of internal audit. Audit Research, 1, 41-43.

Cai, C., \& Tang, Z. (2006). The conceptual framework of modern audit function expansion research. Audit Research, 4, 16-19. 
Cai, Y., \& Jiang, Y. (2006). Discussion on strengthening the supervision function of internal audit. Modernization of Shopping Malls, 18, 17-20.

Chambers, A. D. (1992). Effective internal audits: how to plan and implement. Pitman Publishing.

Chen, J., \& Shen, X. (1981). Introduction to western modern internal auditing. Accounting Research, 4, $48-50+81$.

Cheng, X., \& Zhang, Y. (2006). Empirical research on internal audit model of Chinese listed manufacturing enterprises. Audit Research, 1, 67-75.

Douglas, R, C., Willingham, J. C., \& Schaller, C. A. (2004). Auditing Concepts and Methods. A Guide to Current Theory and Practice.

Fang, Y. (2009). Value-added internal audit research based on corporate governance. Value Engineering Projects, $2,150-152$.

Flint, D. (1988). Philosophy and principles of auditing. Macmillan.

Fraser, I. (2011). In Best-Practice Approaches to: Internal Auditing. Bloomsbury. https://doi.org/10.5040/9781472920409.0017

Gen, J., Xu, X., \& Li, Y. (2008). Research on the motivation and effect of internal audit: Research data from Shanghai Stock Market in China. Audit Research, 1, 35-56.

Goodwin, J., \& Kent, P. (2006). The use of internal audit by Australian companies. Managerial Auditing Journal, 20(1), 48-53. https://doi.org/10.1108/02686900610634775

Guan, J. (1984). The nature and object of China's Internal Auditing. Accounting Communications, 9, 3-6.

James, R. (2000). Best Practices: Value-added approaches for innovative auditing departments. The IIA Research Founding.

Jia, J. (1990). Discussion on internal audit function. Finance and Economics Journal of Shanxi University, 2 , 58-59.

Jia, Y. (2009). Discussion on strategy of internal audit adding value from a strategic perspective. Audit and Economic Research, 24(2), 46-49.

Li, S. (1985). The emergence and development of internal audit in western countries. Journal of Central University of Finance and Economics, 3, 82-83+55.

Liu, C., \& Li, C. (2003). A new probe into the setting mode of internal audit in private enterprises. Audit and Economic Research, 2, 11-13.

Liu, G., \& Guo, H. (2009). Influencing factors and effects of internal audit characteristics: Evidence from Chinese SMEs. Audit Research, 2, 1-42.

Luo, Y., \& Cheng, X. (2013). Internal audit research in the conflict of corporate governance and risk management. Audit and Economic Research, 3, 35-42.

Shen, K. (1984). Establishing the guidelines for enterprise internal audit. Accounting Communications, S4, $19-22$.

Shen, X. (2000). Discussion on the functions of internal audit under the modern enterprise system. Economic Latitude and Longitude, 2, 22-30.

Shi, A. (2009). Research on the internal audit of private enterprises. Economic Issues, 10, 123-125.

Shi, X. (2003). Perspective on the governance function of modern enterprise internal audit. Audit Research, 4, 61-64.

Tan, J., Chen, X., Guo, Q., \& Li, W. (2003). Internal audit of private enterprises: Theoretical framework and development countermeasures. Audit Research, 1, 20-26.

Whittington, O. R., \& Pany, K. (2001). Principles of auditing and other assurance services (McGraw-Hill International Editions). McGraw-Hill/Irwin.

Yuan, Z., \& Huang, Q. (2002). New functions and role of internal audit. Economic Forum, 13, 18-20.

Zhang, X., \& Yang, W. (2012). Research report on the basic situation of internal audit of 36 private Enterprises. China Internal Audit, 11, 10-14. 


\section{Appendix}

The contents of the questionnaires

Basic information of enterprises

Enterprise name

Addresses

Enterprise type

State-owned enterprise

State-asset-holding enterprise

Collective enterprise

Private enterprise

Wholly foreign-funded enterprise

Chinese-foreign joint ventures

Chinese-foreign contractual joint ventures

Others

Industries (Multiple Choices Question )

Agriculture, forestry, animal husbandry and fishery

Manufacturing

Energy (water, electricity, heat, gas production and supply)

Construction

Wholesale and retail trade

Transportation, warehousing and postal services

Accommodation and catering industry

Information transmission, software and information technology services

Finance

Real estate

Leasing and business services

Scientific research and technical services

Water, environmental and public facilities management

Resident services, repairs and other services

Education

Health and social work

Culture, sports and entertainment

Public administration, social security and social organization

The scale of business income of your company in 2015

Less than 3million CNY

Between 3million and 20million CNY

Between 20million and 40 million CNY

Over 40million CNY

Present situation of the enterprise

Listed

Preparing for listing

Unlisted 
Your department

Financial department

Auditing department

Personnel department

Others

Does your enterprise have an Internal Audit Department?

Yes

No

Is the Internal Audit Department dependent enough or not?

Yes

No

Who is in charge of the Internal Audit Department?

General manager

Chairmen

Audit committee

Board of supervisors

Board of directors

Others

Whether the head of the Internal Audit Department is eligible to attend management meetings?

Yes

No

Do you think which level of authorities the Internal Audit Department has in your enterprise?

Relatively high

Generally high

Relatively low

Extremely low

Is there any Internal Audit Charter or other internal audit management system in your enterprise?

Yes

No

Please offer the details on the human resources of the Internal Audit Department in your enterprise.

With _ Full-time internal auditors and _ part-time internal auditors.

_ of them are of professional experience less than 3 years, _ of them are of professional experience between 3 years and 10 years, and of them are of professional experience over10 years.

_ of them are of Master's degree or above, and _ of them are of Bachelor's degree.

_ of them are CIAs (Certified Internal Auditor), _ of them are CICPAs (Certified Public Accountant of China), and _ of them are having other professional certifications.

Which specific knowledge or skills are possessed by the internal auditors within your enterprises?

Foreign languages

Business management

Information system

Finance accounting 
Others

Does your organization support the internal auditors to participate in relevant education?

Yes

No

How much can your enterprise provide for each internal audit per year on professional education?

Less than 1,000 CNY

Between 1,000 and 5,000 CNY

Between 5,000 and 10,000 CNY

Over 10,000 CNY

Compared to the positions of the same level in other departments, the salary of the internal auditors is

Much higher

Higher

Almost the same

A little lower

Much lower

What kind of auditing work has been conducted in the past year? [MCQ]

Financial auditing

Performance auditing

Economic responsibility auditing

Construction project auditing

Risk management auditing

Internal control auditing

Fraud auditing

Information system auditing

Others

The application of computers during auditing work is of

Computer management

Application software assisted auditing

Information system auditing

What kind of weakness do you think the internal auditing work may have in your enterprise?

Lack of human resources of internal auditors.

Lack of professional experiences.

Insufficient supporting funds.

Low level of auditing technology.

Lack of independence.

The audit scope is relatively narrow.

The auditing work is not accepted by other departments.

Others

In your opinion, the objectivity of the internal auditors in your enterprises is

Very high

Relatively higher

Relatively lower 


\section{Very low}

Is the person in charge of the Internal Audit Department is required to report regularly to the superiors?

Yes

No

How often are the internal auditors asked to assist the work of other departments?

Very often

Occasionally

Very few

Never

In your opinion, the internal factors that may affect the development of internal audit mainly include

Corporate governance structure, internal control and internal audit mechanism

Sound internal audit system

The business style of the management

The integrity, professional ethics and competence of the internal auditors

The human resources policy of this enterprise

Others

\section{Copyrights}

Copyright for this article is retained by the author(s), with first publication rights granted to the journal.

This is an open-access article distributed under the terms and conditions of the Creative Commons Attribution license (http://creativecommons.org/licenses/by/4.0/). 